\title{
UCLA
}

Mester

Title

Carlos Fuentes at UCLA

Permalink

https://escholarship.org/uc/item/23d8h6w9

Journal

Mester, 11(1)

Author

Mester, [No author]

Publication Date

1982

DOI

10.5070/M3111013659

Copyright Information

Copyright 1982 by the author(s). All rights reserved unless otherwise indicated. Contact the author(s) for any necessary permissions. Learn more at https://escholarship.org/terms 


\section{Carlos Fuentes at UCLA}

The following is a transcription of a taped public interview of Carlos Fuentes that took place May 15, 1980, at the University of California, Los Angeles. The panelists who directed questions to $\mathrm{Mr}$. Fuentes were Profs. José Miguel Oviedo, Richard Reeve, and John Skirius of the Department of Spanish and Portuguese; and Prof. Raymond Paredes of the English Department, all faculty members at UCLA. The graduate students who staff the editorial board of Mester would like to thank Mr. Fuentes for allowing the publication of this transcription. The transcribing and editing were completed by John Akers and Librada Hernández Lagoa.

REEVE: Carlos, would you tell us a little about your family? Yours is not the typical Mexican childhood. You mentioned your childhood in the capitals of Latin America and in Washington, D.C. In fact, you were almost at the point of losing the Spanish language and only speaking English.

FUENTES: Yes, Richard, I spent my childhood in Washington, D.C., in a very vibrant decade, the decade of the thirties. I was there more or less through the crash and the fair, between the inauguration of citizen Roosevelt and the interdiction on Citizen Kane. I think you are more or less what you eat; you are also the comics you read as a child: I was there more or less between the time Dick Tracy met Tess Truhart and Clark Kent met Lois Lane. My father was counselor of the Mexican embassy in Washington, and he taught me the history, the geography, the story of Mexico-an imaginary country, I then thought, invented by my father in order to nourish my infant imagination. It was a sort of wonderful Land of $\mathrm{Oz}$ with a green cactus road. It was a story of defeats that contrasted exceedingly with the story of victories, of successes, I was taught at the American public schools I went through as a child. To the south there were sad songs, nostalgia; to the north a sense of optimism, progress and faith in the future. I went to school and I was a popular child. One has to be popular at all ages in the United States, and I was popular until a certain day in May - to be precise it was the 18th of May in 1938-when I suddenly ceased to be popular. What had happened was that Lázaro Cárdenas, the President of Mexico, had expropriated the foreign oil holdings, the companies that held Mexican oil. I suddenly became a pariah in my school. The newspapers of the time were full of blazing headlines denouncing the Communist government of Mexico, threatening President Cárdenas and demanding sanctions against Mexico. Some were even demanding the invasion of Mexico in the sacred name of private property. There were epithets in my school; there were even blows. Children know how to be cruel, and the cruelty of elders is basically a residue of that malaise we feel from childhood toward things, other things, strange things that we do not understand. But this political 
act suddenly revealed to me that my country existed, that it was not a figment of my father's imagination made to entertain me, and that I was part of it. I saw pictures of Cárdenas, and he did not belong to the glossy repertoire of American ideals. He was a "mestizo," a man of mixed blood, Indian and Spanish, with a grim far-away look in his eyes that made him look as if he were trying to remember a mute and ancient past. I asked myself, "Is this past mine as well? Is this identity mine as well?" It was a tremendous revelation that my identity was Mexican, an identity that I really did not complete until the second stage of my childhood.

I followed in my father's footsteps in the early 40's and went to Chile. Chile in the early 40's had a government of the Left: the Popular Front of Pedro Aguirre Cerdá. It was a country that vibrated with democratic activity, political campaigns, electoral campaigns, active parties, active unions and active newspapers. It was also not by mere coincidence the country of the great Latin American poets: Gabriela Mistral, Vicente Huidobro, and Pablo Neruda. It was a politically verbalized country, because it was also a greatly verbalized country at the level of literature, at the level of hope. This was a great second lesson for me.

I met Neruda only many years later. I've always thought of him as a King Midas of poetry who really turned everything he touched into poetry. I remember that once I visited the region of Lota in southern Chile where the coal mines are and the miners go deep into the Pacific Ocean to extract the coal. They come out on their knees from their daily work, and on that occasion when I was there they sat around the bonfire with guitars and sang a song that I quickly recognized as a poem by Pablo, a poem from the Canto general. When they ended, I said how happy the author would be to know that his poem had been set to music. They stared at me blankly and said, "What author?" They thought it was anonymous poetry that came from afar, from the origins of time, like Homer's poetry.

That was another great revelation to me: to have my identity as a Mexican, and then to understand that I could only give light to that identity, give expression to that identity, through a language, the Spanish language. I became a writer in the Spanish language, a man who only knows how to dream and insult and make love in Spanish. I know a challenge in the Spanish language I did not feel in the English language. I thought there was something to do with Spanish that I did not feel with English. I thought that the English language knew how to take care of itself, and that if it ever became drowsy there would always be an Irishman who would come along ...

REEVE: That leads us into Raymond's question about English literature.

PAREDES: Yes, my question has to do with influences. William Faulkner is often cited as the writer from the United States who has an enormous influence among writers from Latin America, perhaps an even greater influence there than here. What is it about Faulkner that is so appealing and so compelling to writers from Latin America? 
FUENTES: You're absolutely right about Faulkner, Professor Paredes. You know, sometimes we say that Latin America starts south of the Mason-Dixon line: it is our way of appropriating Faulkner for ourselves. When I think of this vast influence of William Faulkner in Latin America-which as all influences is more than an influence, a coincidence, a deep coincidence-I believe it is because he knows the people and talks about defeat. The great gulf between the U.S. and Latin America has been a gulf between a success story and a story that has been very difficult, the story of defeat. Seventy-five percent of the history of the world has been a history of defeat. The U.S., upto Vietnam, has an exceptional history of successes. It is very difficult to identify with success, especially when you are not successful; but you can identify with defeat, especially with tragic defeat and the work of William Faulkner. What do I mean by this? I mean that the sense of defeat in Faulkner is not manichean or moralistic. Faulkner is not singling out those who are guilty, as you would do in the spirit of melodrama. He is a tragic author, a profoundly tragic author who is saying we are defeated because first we defeated ourselves; he is saying we defeated ourselves because we divided ourselves as we divided our lands. The name itself of the mythical county of Faulkner, its Macondo of the South, Yoknapatawpha, comes, of course, from a combination of two Chickasaw words that mean "the divided land." The South was defeated by the South before it was ever invaded by the North. The reconstitution of the community, the reconstitution of unity, the rural concept of time that makes the past present, that brings the past back to us, that gives priority to the instant and not to the illusion of the future as a time in which the values of tragedy can meet and perhaps reconstitute unity and community, is, I think, a great literary lesson.

This lesson gave us a vision that was coincidental with the needs of Latin America. Besides, Faulkner used a mythical procedure, not only a tragic reality but a mythical procedure-this also was a profound coincidence with our cultures that have very strong mythical elements, especially those that are rooted in the Indian "castas," as in the case of Mexico. But there is something that always struck me in the reading of Faulkner and then in the reading of the mythical and tragic writers of Latin America, such as Juan Rulfo in Pedro Páramo. It is interesting to know that "myth," which finally came to mean "the word of words," "mythos," originally had the opposite meaning. It comes from the Greek, "mou," which is exactly what it sounds like, what the cows do, "moo," which is an inarticulate expression. From "mou" is derived "mystos," which means "mystery," and finally "mythos," which means "the word of words." This transmigration of words I find very interesting because in Latin the word "mutus," which means "mute," becomes the French word "mot," which means "word." I think that this curious reunion of myths and mysteries and "muerte," and I would say "Mexico," to go on with the m's, is something that Juan Rulfo, who is a good reader of Faulkner, achieves splendidly in our own literature. So, we have here a brilliant example of how literature communicates with itself, breaks 
down barriers, breaks down frontiers and permits us to achieve this transition from the "moo" of the cow, to the "mythos," the word of words; permitting us to go from silence to articulation to human expression.

REEVE: Our next question comes from Professor Oviedo. We have asked him to give one of his questions in Spanish for those of you who would like to compare the beauties of his Peruvian dialect with the Mexican dialect of Carlos' answer.

OVIEDO: Con bastante frecuencia tus novelas, Carlos, parecen haber sido escritas a partir de modelos reconocibles y explícitos que provienen de la misma tradición novelística en algunos casos: Under the Volcano para Cambio de piel, por ejemplo; o del cine, "Citizen Kane," para La muerte de Artemio Cruz; o del arte, como Bosch, Signorelli y tantos otros para Terra Nostra. ¿Qué relación se establece entre esos modelos y tu obra propia? ¿Por qué, con qué intención los escoges? ¿Para reinterpretarlos, para parodiarlos, para negarlos ... .?

FUENTES: Bueno, mira, me planteas ejemplos de tres novelas mías: La muerte de Artemio Cruz, que apuntó bien, Cambio de piel y Terra Nostra. Déjame despachar las cosas un poco en orden, porque por lo que hace a La muerte de Artemio Cruz es indudable que contiene un homenaje a "Citizen Kane" y a la obra de Orson Welles, y te voy a decir por qué: mi padre me llevó de la mano en 1939-40 a ver la película de Welles cuando se estrenó en N.Y., y para mí fue la revelación del mundo. De repente entendí el mundo, la política, la pasión, la ambición, el orgullo, la derrota, mil asuntos; y en cierto modo quise hacer un homenaje a Welles. Pero hay una cosa: no veo lo que dices respecto a Cambio de piel y la novela de Lowry, Under the Volcano. No veo tan cerca las dos obras en el sentido de que la obra de Lowry es una obra esencial y muy desesperada, mientras Cambio de piel es desesperada pero superficial en lo popular de la cultura urbana para de esa manera consagrarla y darle viabilidad literaria.

OVIEDO: Estamos hablando en realidad de lo que se hace con la tradición porque mi pregunta parte de la convicción de que en la literatura no hay creación a partir de la nada. No hay creación "ex-nihilo", sino que toda obra nace de una tradición. Es decir que la nueva creación presupone una tradición.

FUENTES: Los libros siempre vienen de algún lado; generalmente son hijos y nietos de otros libros. Yo creo que Madame Bovary está mas cerca de Don Quijote que de la historia de una mujer provinciana que se suicida, la que leyó Flaubert en una gaceta. Es menos importante eso para Madame Bovary que la nieta de Don Quijote. Madame Bovary es un Quijote con faldas que cree en lo que lee, se vuelve loca y se mata. Malraux en su testamento literario dice que no es concebible la poesía de 
Rimbaud sin la poesía de Banville. Es una inflexión que prolonga una tradición, la trasciende y la supera, desde luego. Yo creo en la realidad de la tradición, la extracción de las obras literarias, en una tradición.

Pero en seguida me mencionas una cosa que me interesa mucho porque ya no tiene que ver con la tradición y es la presencia de ciertos cuadros famosos en Terra Nostra. La presencia de esos cuadros de Signorelli y Bosch tiene un papel muy importante para la novela, un papel estructural; ayuda a estructurar esta obra que, después de todo, es una obra obsesionada con los orificios, con los hoyos, incluyendo los hoyos de la mirada. Es una obra de miradas en la que el sujeto no se reconoce en el objeto del espejo sino que ve una ausencia. Esa ausencia se llama su deseo. A partir de esta negación del sujeto en el reflejo se establece una dialéctica de la obra que podríamos llamar la dialéctica de la accesibilidad y de la inaccesibilidad del hoyo por el cual se puede salir de la prisión, pero con el terror de ser expulsado al mismo tiempo del hogar. En esta tensión creo que se desarrolla toda la obra. El Escorial en esta creación es una especie de prisión que va a evitar Felipe Segundo con el terror de estar enterrado en vida y el de ser expulsado. El terror de todos los personajes de esta obra es el mismo. Es el terror de la señora, la reina, porque no ha sido desvirgada por el rey, proque tiene que ser un ratón el que le coma el coño. Otra vez el hoyo porque el señor, el rey, nace en una letrina, en un hoyo, porque su padre quiere contar con la inaccesibilidad de las ropas de la reina y nunca llegar a ella. Pone ese pretexto porque Felipe no es capaz de tomar a una campesina que se llama Celestina y tiene que dejar que su padre lo haga. Por lo tanto tiene que negarse a toda penetración por Felipe, llamar sólo a una mujer a la cual no puede tocar, que será esta Isabel que quiere ser tocada como no lo es por su esposo. Finalmente lo es por su hijo en la violación de lo inaccesible que es el incesto a través de este Don Juan que posee a su madre y termina condenado a vivir en una prisión de espejos, comido por la vagina de la monja Inés. Mientras tanto su padre, el rey, se pudre en una enorme tumba-prisión de piedra, y la reina construye con retazos de las momias reales, una momia final, la momia de España que constituye el horror supremo del Barroco. El Barroco, nuestro Barroco, tiene este sentido de darle vida a lo monstruoso, la monstruosidad final de lo accesible y de lo inaccesible; parto de Signorelli, parto de Bosch, parto de la mirada y de los hoyos del cuerpo, en este renacer de un muerto. Finalmente lo que propone Terra Nostra es el horror supremo delirante que merezca el poder de nacer de un cuerpo muerto-y me pregunto si no nacimos todos de un cuerpo muerto en la América Española.

SKIRIUS: You have shown interest in urban problems of Mexico City in your novel La región mas transparente, which was first published in 1958 and translated into English as Where The Air is Clear. Now, today, in 1980, Mexico City has about 14 million inhabitants, and if the projections are true and the present birth rate continues, by the year 2000 greater 
Mexico City may have up to 40 million inhabitants. My question is threefold: What kind of urban problems and urban life styles do you foresee, not only for Mexico City but for other great metropolitan centers such as Los Angeles, in the next 20 years? Secondly, would you want to live in such a city? And thirdly, could you see yourself writing a sequel to La región mas transparente?

FUENTES: Can I answer you by mounting on my horse? . . I have written a sequel to La región mas transparente, La ciudad perdida, which appears in Mexico in August, and I think the best thing I can do is answer you by. reading a passage that expresses my fears of things that might happen not only in Mexico City, as you have very justly said, but in all these great urban centers which are seething with violence.

[At this point Carlos Fuentes read a selection from Agua quemada, eventually published in Mexico by the Fondo de Cultura Económica in 1981. See "La brigada," pp. 131-133. To date, La ciudad perdida has not been published.]

REEVE: In 1956, Selden Rodman, a journalist, talked to you about a story, which you never did write, in which Mexico became the fifty-first state of the U.S. In 1975, in Terra Nostra, you have the U.S. invading Mexico and its last remnants, the guerillas fighting for their independence in the mountains around Veracruz. Are you that pessimistic about the relationship between the U.S. and Mexico? How do you see the future of the U.S. and Mexico?

FUENTES: Now let me say first of all-you mentioned my fictional story -that I wonder if three years from now the U.S. will not be asked to be admitted to the Mexican union? But you know the story, which I will finally write in a book called Political Fictions, in which Mexico is admitted as the fifty-first state, and then rapidly proceeds to demoralize the U.S. senators and deputies in Washington - and they take care of matters rather quickly - so the U.S. says, "Now please get out of the union, and you can have the whole Southwest back again." Mexico says, "Thank you very much: we accept everything except Texas." Our problem right now is twofold: One is that we do not want to interfere in the internal affairs of the U.S. We've always defended non-intervention in our own affairs. Secondly, we do not want the U.S. to depend overly on Mexico; we want the U.S. to become independent of Mexico, especially as regards oil. There is a problem of understanding, obviously, and it derives from so many facts: we are different. There is something more than a frontier between the U.S. and Mexico. One has to think it's a very important frontier because it's also the frontier between the U.S. and all of Latin America. . . . It's also the frontier betwen the U.S. and all the Third World, the only one. In fact, it's the only frontier between a highly industrialized Western nation, capitalistic nation, and the Third World. We are different. We are Shiites, Mahayana Buddhists and orthodox 
Augustinians; you are Sunnies, Hanayana buddhists, Carolingian heretics. We come from the abundance, the Catholic largesse, baroque largesse of Rome; you come from the-how should I say it-"estreñimiento" of Protestantism, of Luther. You have a problem we have solved: How do you transform Pocahontas into the Virgin of Guadalupe? But we have a problem too: How could we retransform Montezuma into a member of the Kennedy dynasty? How could we make a ritual out of eating a hamburger at McDonalds? How could we computerize an enchilada? How could we say in Spanish "to be or not to be," since in English we cannot distinguish our "ser" from our "estar"? The differences are there; the legality is different. You descend from the common law; we are descendants of Rome, the sense of Roman law through Spain. Law only exists if it is written; for you, law exists in custom, in the creation of the community. You were prosperous from the very start. England was the rising mercantile and capitalistic power of the 17th century. We were, in a way, the colonies of the colony. One reads Alonso de Carranza, a Spanish economist writing in 1629, who said that in 1629 already seventy-five percent of the bullion gold and silver from the mines of the New World had slipped through the hands of Spain and ended up in four European cities: Rouen, Amsterdam, London and Paris. "Let us sell merchandise to the Spanish," ordered Louis 14th of France in a famous letter, "and get the gold from them." They squandered it. We were, as I say, "economically deformed" from the very start.

The differences between us are very great: I think that the basic issue, the issue from which all depends is really the one that the President of Mexico, López Portillo, has approached in his conversations with your President, Jimmy Carter. We must first of all understand ourselves as two different nations with different physiographies. Let us identify each other; let us understand the problems globally. We can't start out by dealing with tomatoes only, and then when tomatoes are stalled, a desert: nothing happens. Mexico is surprised because, suddenly, there is a "dumping," there is an operation intercept, or the tortilla wall is erected; everything is done by surprise, Mexico is taken by surprise-without proper consultation-basically because there is not the understanding that Mexico is a civilization, that Mexico is, as I have said before, a nation and not an oil well; it is first of all a nation that has to be understood. We have to understand the U.S., I agree, but first of all there must be this fundamental act of identifying each other and of identifying our respective national interests: they are not the same. The U.S. must stop thinking of its foreign policy in terms of friends and enemies. No such thing exists. There are different national interests, and these national interests must be perceived mutually as valid, as honorable. Because they differ from the interests of the U.S. does not mean they are evil. The U.S. government loves to think in terms of good guys and bad guys, white hats and black hats. Reality is not like this. This is what I can say to start with-because I know we will talk more of it-but sometimes I look at the problem with 
desperation, and I ask myself, "Does the U.S. have a foreign policy at all, or does it only have Barbara Walters?"

PAREDES: My question is related to the previous one. What is your view of the future relations between Mexican-Americans and "mexicanos"? As you know, Mexican-Americans often feel slighted and despised by Mexicans. Is this feeling justified, and do you think the situation will improve?

FUENTES: I think there has been a counter-revolution of public opinion. It is true that there have been times in the past when Mexican-Americans were considered as "pocho." I think that in the last few years there has been an evolution from "pocho" to ally. There is the possibility of -why not say it clearly? - of having a Mexican lobby in the U.S., the same way Israel or Greece or any country seems to have a lobby. Why don't we have a lobby? I think that more and more we will realize that we live in a world not of self-sufficiency-which is impossible-but of self-reliance and of cultural identification. I think it is very important to understand that what we are seeing right now is a death of ideologies. After all, only two ideologies have been paramount in the world, and they are in some ways similar to each other. Both come from the eighteenth century, from the great faith in human perfectability and progress, and they have been, in a way, unmasked or degraded by the terrible cruelty of the twentieth century. What are now appearing on the stage of the world are the cultures, the deep cultures, of nations, of groups of nations, historical continents, Islam, China, Japan, Western Europe, Slavic culture, the culture of Latin America and the culture of the U.S. The Mexican-Americans belong to the U.S., but they are close, very close, to the culture of not only Mexico but of Latin America and of the Hispanic world. I think we should act as a culture; I think that there is much to be done for the good of peace and good relations, of good understanding between the two nations through the friendship between Mexicans and Mexican-Americans. I think we are rapidly moving from a bipolar to a multipolar world, and all that it implies. The two great powers creak under the tensions created by this escape from the equilibrium of terror and the self-hypnosis imposed by the post-war period. Nations are wrestling to create new centers of powers, to create a multipolar world. I think Mexico has achieved a specific weight, a specific importance. It has a long tradition in foreign relations, in the construction of a nationality and of a national state, and is ready to play an important role in this new multipolar selfreliant-not self-sufficient-world. I think we need to help MexicanAmericans. I think we will need your help in order to identify before the American public the nature of our relations, the physiognomy of our culture. I think we will need your help to make it clear to the American government and to the public opinion of this country that what our country is fundamentally looking for is a better world in which to live, with a new world economic order. The U.S. has been very slowly recog- 
nizing the necessity for a new world economic order. The order created at Breton Woods after the Second World War no longer exists. There is a decolonized world. There is a totally different picture, and we are still ruled by the visions of 1946 . Something new has to be created. I think that the Mexican-American can make the U.S. understand that many of the things Mexico and the Third World are looking for are no more than what the U.S. gave to itself through legislation to resolve deep social problems, to give attention to deep social demands. I think of the social advances of the Social Security Act of 1933 or '34, the Fair Labor Relations Act of 1938, the Equal Economic Opportunity Act of 1964. All these great pieces of legislation in the U.S. are what Mexico is demanding for in the new world economic order. This should be understood in the U.S., but instead I hear that Willie Brandt comes to Los Angeles, and he is denied access to television. He is not on television; he cannot explain the contents of his new book on relations between the North and the South.

I think you can help, Mexican-Americans, can help public opinion and the government of the U.S. see that we have to submit the very powerful multinational companies to legal order, that they cannot operate without any legal boundaries. These companies are enormously powerful. Their gross product amounts to eight hundred thirty billion dollars, which is the equivalent of the total gross national product of all the Third World with the exception of the oil-producing countries. They account for thirty percent of the commerce of the world, and yet they act without any boundaries. They transfer prices as it interests the companies and not the nations in which they operate. I think here there is a voice also. You are a mirror to the American public opinion, to the American government. I think that in this growing world, in this growing multipolar world, in this world in which Mexico, I assure you, will no longer be a defensive subject but an active subject of international relations, I think it is important for you to help us make the American public and government understand that great changes are being wrought in Latin America, in Central America - to be precise, in Nicaragua today; tomorrow, Guatemala, El Salvador-and that it should be understood that probably these governments will go very much to the left, call themselves socialist, but that they will only become stooges of the Soviet Union if the U.S. forces them to be such. The U.S. must open with your help, with people like you, all these wonderful people that I've met in Los Angeles. We should make the U.S. understand that there will be plurality in the world, that there will be competition, that in Nicaragua the U.S. should compete with Germany and the Soviet Union, and nothing extraordinary will happen. There is great opportunity for the "nicaragüenses," who after the devastation of civil war have launched a campaign against illiteracy in which I think we should all collaborate. Mexico is helping Nicaragua with oil, with teachers, with technical assistants. We will not let Nicaragua stand alone and isolated as was the case 
of Cuba in '59. This mistake should not be repeated. The U.S. should give the new regimes in Central America nothing more and nothing less than that which during forty years it gave to Somoza and to all the dictators whom it helped to improve.

SKIRIUS: Carlos, the same political party has run the Mexican federal government for years, as we know. Do you think the P.R.I. will hold its almost monopolic control of the government bureaucracy much longer? Let's take for example the new factor of the oil discoveries. I know that you wrote a novel, The Hydra Head, with an international espionage scene of dispute over this new oil. Might this be a factor of instability in the fall of the government? Or might it be a factor of stability in that the P.R.I. would actually distribute the wealth for more reform programs so that it would become an authentically revolutionary party again? If not, what might we expect to happen in Mexican politics?

FUENTES: You've really asked me a $\$ 64,000$ question. Let me try to tell you what I believe. Several things: Mexico is a country that has on many occasions been invaded, humiliated, mutilated, because it could not pay its debts. The Juárez moratorium on foreign debts triggered the intervention of the French and the creation of the empire of Maximillian of Hapsburg. In 1838, there was a mutiny in Mexico City and the pastry shop of the French "boulanger," M. Remontel, was destroyed. He protested, asked to be paid, asked for the intervention of the French government; and they sent an "armada" to Veracruz in order to protect the private property of Monsieur Remontel. This was called the "War of the Pastries" in Mexico. We had a commission, a mixed commission of reclamations, to pay for many problems of this nature created during the Mexican revolution. President Cárdenas refused to compensate the expropriated companies in ' 38 because he felt that money should be used in order to promote agrarian reform and give the country something to eat at the same time it was developing its own oil industry. So when President López Portillo now says that Mexico for the first time in its life will be financially independent, this means a great deal in Mexico because of our past history.

Let me draw another parallel to what I just said. Mexico succumbed to the U.S. in the war of 1846-48 because it was a totally disorganized, anarchical country. The eruption was the liberal revolution of 1854 , and the decision of Juárez and the men of the liberal revolution was that what happened in ' 48 should not happen again; that Mexico should have a strong, national, liberal state in order to be able to preserve its territorial integrity and its power of self-determination. Now we have these vast oil wells that I believe are calculated to be able to produce something around 150 billion barrels (notably inferior to the oil wells of this countryprobably the greatest producer in the world at around 700 billion barrels); but, of course, the U.S. would rather see that others use their oil before it even touches its own. That's another problem. 
We have the opportunity now to solve many age-old problems. I think that the Mexican state, this state which is born really from the revolution of the liberals headed by Juárez in 1854 , is very conscious that if it misses this opportunity it will be committing suicide. This is its last opportunity. If the people see that the government is not solving problems with an income of 18 billion, 20 billion, 25 billion dollars a year from oil exports, then private enterprise in Mexico will say, "Move over, I can administer the oil if you cannot." It will administer the wealth for its own benefit, I assure you, not for the benefit of the community and the Mexican people. What the government can do is to administer in benefit of the inajority. I think that there are temptations to do things wrong, to perhaps funnel too much wealth toward the private interests to resurrect the Hamiltonian theory that wealth accumulates at the top and then drops down toward everyone else-something that has not happened, has never happened and will never happen. There could be the temptation of creating a sort of fake welfare state, of subsidizing poverty, of subsidizing mendicity, as it were. There is the ever-present danger of corruption, but there is perhaps also a clearsighted political, economic, social and human decision to finally solve many secular problems of our country. We have great problems of unemployment, the demographic problems and the problem of agriculture. If Mexico grows at its present rate, in about 20 or 25 years we will be using all the money we received from oil in order to pay for the food we import from abroad: this cannot be. I understand that there is a new national project for development that has been recently published in Mexico City, and President López Portillo has put special emphasis on solving the problems of Mexican agriculture in creating something called the "Mexican Food Systems." In order to go to the bottom of the problem, I agree that consequently, as I have always said, the first priority is to restore the Mexican agricultural base. I'm thankful this is what the government has seen as its priority. Now, about the political situation with this particular economic perspective: the country changed very much in 1968. '68 gave a great jolt to Mexican society and to the Mexican state that had fallen asleep on its laurels. It was a self-congratulatory state that was shaken out of its complacency, out of its somnolence, by a rebellion of urban, middle-class youth. It was caught unaware and it responded brutally, with masacre, with blood. I think that it says a great deal about Mexico that instead of going to the pits of a repressive military dictatorship as in the southern part of the hemisphere, Mexico was able to offer other alternatives, other solutions, in order to avoid the repression. I think that it was the function of the Echevarría government to open up the society and create an equilibrium that permitted the present government to do an important thing, which was to initiate the political reform that has taken place. Under the acts of the present government, the Communist party may operate within the political system and have real participation in the Congress. Where particularly the Communist deputies have been very active, very agile, is 
torpedoing initiatives from the executive and making the executive feel it is no longer all powerful, that there is an opposition for the incompetent. But there is an even more important fact in the political reform. As you know, the P.R.I. has always legitimized itself by saying, "There is no left to the left of the P.R.I. We are the left; we are the revolution. There is nothing to the left." Suddenly, there is something to the left, and the P.R.I. admits it. That is a change in the distribution of political power.

SKIRIUS: So you see there is still a resilient, strong party. You expect it to last much longer.

FUENTES: You know they are "mucho más maquiavélicos que las arañas".

REEVE: We won't translate that . . .

FUENTES: You know that General De Gaulle sent a commission of twelve experts to Mexico to study the P.R.I. and to see if he could reproduce it in France. It is a very efficient political machine, but it creates very many problems, especially since Mexico is more and more a diversified society; and even though the P.R.I. is more ideologically diversified than your two-party system. There are more ideological tendencies within the P.R.I. than you find between the Republican and Democratic parties-and even John Anderson-in this country. Still, I think that the solidification of a society, of a culture, demands a greater participation in pluralistic organizations. I think numerous organizations are there. I was present when some young communists visited President Echevarría in 1970 and asked for the legalization of the party; and he said, "Sure, when you really have a party. You don't have a party right now: you have two thousand members and half of them are members of the CIA. Go and work in the factories; achieve a proletarian base." They have done that, they have worked in a organized fashion, and I think that now the Communist party in Mexico is a real political party with real roots in the working class. It is destined to grow and have a very important role in the future. Any of the parties that disagrees with the Communist party or the parties of the left will also find its support and its clientele. I believe that we are going toward a multi-party system in Mexico.

OVIEDO: El poeta Jorge Zalamea decía hablando de la poesía primitiva de la América hispana que en poesía no hay poetas subdesarrollados. Tú has señalado alguna vez que la novela moderna tiene hoy dos centros: América Latina y el mundo Centroeuropeo. ¿Cómo es y por qué crees que se ha producido esta situación?

FUENTES: Yo creo que básicamente lo que sucede es que la novela tiene mucha importancia en América Latina y en Europa Central. Aclaro que cuando hablo con los novelistas de Hungría y Checoslavaquia, dicen que no están en Europa oriental. Ven el mapa, estamos en el centro de Europa, 
y el oriente de Europa es otra cosa. En Moscú es otra cosa. Yo creo que la novela está muy viva en estas dos regiones del mundo porque en ellas hay mucho que decir, y la novela es la forma literaria de la máxima amplitud para decir todo lo que no se podría decir de otra manera. Yo creo mucho en la vitalidad de la novela, en su misión, en su función, en su vigencia. Cuando me pregunto a mí mismo en dónde empezó el mundo moderno, no pienso nunca en la caída de Constantinopla en manos de los turcos, la publicación del sistema de Copérnico o en el descubrimiento de América. Pienso que el mundo moderno nació un día de 1605 en que un caballero que subió a su caballo salió con los caminos de la Mancha. Se llamaba Don Quijote. Es el fundador del mundo moderno porque lo que hace Don Quijote, a través de la forma de la novela, es dejar atrás el mundo de la certidumbre medieval, en el que todas las cosas se parecían a sí mismas y lo que se leía era verdad, para salir a un mundo en el que nada se parece ya; y en el que hay que volver a encontrar la analogía de las cosas sin sacrificar su diferencia y las diferencias, sin sacrificar la analogía, un mundo esencialmente conflictivo que es el mundo del humanismo moderno, del humanismo renacentista. Don Quijote es el caballero de ese mundo, y nos guía hacia ese mundo a través de la forma de la novela, pone en duda el mundo, lo que es función de la novela, y sabe a la vez que la novela nace de la historia, que surge de la historia, pero que a través de su libro y de toda gran novela lo vemos también salir de ella para contemplarnos a nosotros mismos, para no ser víctimas ni de nuestro individualismo, ni del excesivo peso de una abstracción histórica. A través de la novela el hombre es reintroducido a su destino, a su lenguaje; yo creo que esta función es particularmente aguda y exigente en la América Latina y en Europa Central, pero no deja de ser una función que está reencontrando una sensibilidad que se entiende en todo los países. La novela es una de las grandes creaciones de Occidente; es una de las grandes creaciones de la civilizacíon. Creo que es una salida intelectual muy importante en el futuro que yo creo que jamás será sacrificado. 